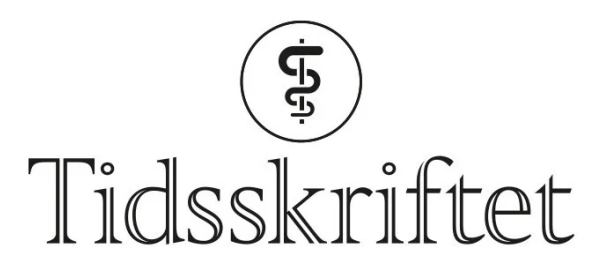

DEN NORSKE LEGEFORENING

\title{
Helsespråk i klarspråk
}

\author{
ANMELDELSER
}

JOHN NIKOLAUS NESSA

Pensjonert fastlege i Hjelmeland

Erlend Hem, Magne Nylenna, red.

Helsespråk

223 s, ill. Oslo: Tidsskriftet Michael, 2021. Pris: åpent tilgjengelig på www.michaeljournal.no ISBN 978-82-92871-77-5

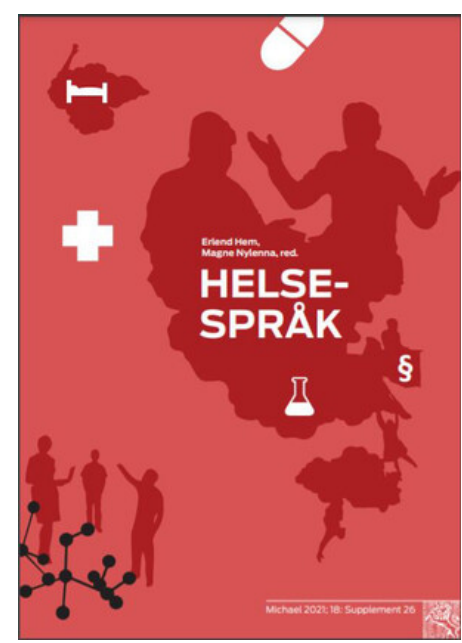

Professoren i hematologi raljerte over vestlendingen som under patologieksamen kikka i mikroskopet og såg «berre prikkar». Han strauk med glans. Det var ikkje synet eller mikroskopet det var noko gale med, det var språket. Han forstod ikkje at det var lymfocyttar han såg.

Det er sjølvinnlysande at skal du lære deg hematologi, må du lære deg kodesettet for hematologi. Det er også sjølvinnlysande, men nettopp derfor også skjult for dei fleste, at det gjeld for heile medisinen. I alle krikar og krokar av helsevesenet både begynner det og sluttar det med språket. Medisin er også språk. Derfor er det på høg tid at det blir produsert forskning og litteratur om dette. 
Erlend Hem og Magne Nylenna viser at dei tar dette på fullt alvor. Dei har redigert ei bok på 23 kapittel og er sjølv medforfattarar saman med 26 andre bidragsytarar. Vi får ei innføring i språk generelt og det medisinske fagspråket spesielt, med referanse til språkfilosofi og generell kommunikasjonsteori.

Direktoratet for e-helse arbeider med å innføre eit felles helsespråk. SNOMED CT er ein internasjonal, klinisk, tverrfagleg og maskinlesbar terminologi med over 350 ooo omgrep som er sett i ein definert relasjon til kvarandre. Dette er greitt å vite når vi som brukarar kanskje slit med å finne den rette koden og gjerne ønskjer ein annan, eigenprodusert kode.

Klart språk er ikkje ein floskel. Det er ikkje sjølvsagt at vi bruker eit klart språk når vi snakkar eller skriv. Klarspråk er blitt eit krav til helseføretaka, ikkje minst etter innspel frå ulike brukarutval, og det er også det som er den raude tråden i boka.

Når eg les nye bøker, les eg siste kapittel først. Denne boka sluttar med ti tesar om klart språk. Johan L. Tønnesson klarer på få sider både å fortelje og å vise, ved å inkarnere Espen Rostrup Nakstad som eit klart språk i ein naturbegava kropp, at klart språk ikkje er enkelt. Men klart språk er både ønskeleg og mogeleg.

Boka har få illustrasjonar, men enkelte bra bilete. Ho overlevde ikkje mi lesing. Sidene ramla frå kvarandre før eg var ferdig med alle tekstane. Men noko må ein ofre skal ein få eit produkt som er miljømerka. Alle som er opptatt av helseformidling, bør lese denne boka. Om de ikkje orkar 220 sider, les dei siste ti først.

Publisert: 30. september 2021. Tidsskr Nor Legeforen. DOI: 10.4045/tidsskr.21.o616

(C) Tidsskrift for Den norske legeforening 2023. Lastet ned fra tidsskriftet.no 26. april 2023. 